\title{
Leaf Spot Disease of Spinach in California Caused by Stemphylium botryosum
}

\author{
Steven T. Koike and Diana M. Henderson, University of California Cooperative Extension, Salinas 93901; and \\ Edward E. Butler, Department of Plant Pathology, University of California, Davis 95616
}

\begin{abstract}
Koike, S. T., Henderson, D. M., and Butler, E. E. 2001. Leaf spot disease of spinach in California caused by Stemphylium botryosum. Plant Dis. 85:126-130.

Beginning in 1997, a new disease of spinach was found in the Salinas Valley, Monterey County, CA. Initial symptoms were leaf spots that were 2 to $5 \mathrm{~mm}$ in diameter, circular, and gray-green in color. Spots later enlarged, turned tan in color, and became dry and papery in texture, resembling phytotoxicity due to agrichemicals. Although fungal signs were generally absent from the spots, Stemphylium botryosum was consistently isolated and caused identical symptoms when inoculated onto 20 spinach cultivars. Three isolates did not cause disease symptoms when inoculated onto other crop plants representing 16 different genera and a Chenopodium weed species. A fourth isolate showed similar results with the exception of small leaf spots occurring on inoculated fava bean. Isolates produced a Pleospora herbarum teleomorph after 7 months incubation at $5^{\circ} \mathrm{C}$. Preliminary experiments with cell-free culture filtrates indicated that phytotoxins apparently were not produced by these isolates. This is the first report of a foliar spinach disease caused by $S$. botryosum.
\end{abstract}

Additional keywords: pesticides, phytotoxicity, Spinacia oleracea

Spinach (Spinacia oleracea L.) is an important leafy vegetable grown in four major agricultural regions of California: southern desert valleys, southern coast, central coast, and the central San Joaquin Valley (21). In 1997, over 8,500 ha of fresh market spinach were grown having a gross value of $\$ 55.5$ million, and close to 30,000 metric tons of processed frozen spinach were produced with a gross value of $\$ 4.7$ million (6), making California the leading producer of spinach in the United States (23). The California spinach crop almost exclusively consists of flat leaf, or "nonsavoy," cultivars. Approximately half of the state's spinach crop is produced in the Salinas Valley, which is located in the central coast region of Monterey County. The moderate climate in this coastal location allows spinach to be grown 12 months of the year.

Spinach production in the Salinas Valley involves exceptionally high seeding rates. Spinach grown for processed frozen, standard fresh market, and fresh market "baby leaf" (harvested at the four- to five-leaf stage) products is planted at 1.9 to $3.1,6.2$ to 9.1 , and 9.1 to 18.5 million viable seed per ha, respectively. Such high plant densities create conditions that may favor the development of various foliar diseases,

Corresponding author: S. T. Koike

E-mail: stkoike@ucdavis.edu

Accepted for publication 23 October 2000.

Publication no. D-2000-1206-01R

(C) 2001 The American Phytopathological Society such as downy mildew, caused by Peronospora farinosa f. sp. spinaciae, Cladosporium leaf spot, caused by Cladosporium variabile, and anthracnose, caused by Colletotrichum dematium $(7,17,19)$.

In 1997, 1998, and 1999, unusual foliar symptoms were observed on commercial spinach in the Salinas Valley. On immature and mature leaves, initial symptoms consisted of leaf spots that were 2 to $5 \mathrm{~mm}$ in diameter, circular to oval in shape, and gray-green in color (Fig. 1). As the disease progressed, leaf spots expanded, remained circular to oval in shape, and turned tan in color. Older leaf spots coalesced, dried up, and became papery in texture. Leaf spots could enlarge and result in death of significant portions of the leaves (Fig. 1). Overall on both fully expanded and young leaves, symptoms strongly resembled the tan, circular spots caused by pesticide and fertilizer spray damage (Fig. 1). Visual signs of fungal growth also were generally absent from the spots; hence the foliar symptoms were not due to downy mildew, Cladosporium leaf spot, or anthracnose. The purpose of this study was to determine the cause of this leaf spot problem and characterize the pathogen. A preliminary report has been published (18).

\section{MATERIALS AND METHODS}

Isolation of the causal agent. Symptomatic leaves were surface-sterilized by soaking leaf pieces in $10 \%$ bleach $(0.525 \%$ sodium hypochlorite) solutions for $3 \mathrm{~min}$. Small $(3 \times 3 \mathrm{~mm})$ sections of tissue were aseptically excised from leaf spot margins and placed into petri plates containing potato dextrose agar (PDA; Difco Labora- tories, Detroit, MI) that was acidified (2 ml of $25 \%$ lactic acid per liter). Plates were incubated in light from a combination of cool-white and Vita-Lite fluorescent tubes on a 12-h light-dark cycle at $24^{\circ} \mathrm{C}$ and examined after 3 to 10 days for fungal growth. Monoconidial cultures of isolated fungi were subsequently stored on PDA slants at $5^{\circ} \mathrm{C}$. To test for possible bacterial pathogens, small pieces of the surfacesterilized leaf spots were aseptically excised from leaf spot margins and macerated in $40 \mu \mathrm{l}$ of sterile distilled water. The resulting suspensions were streaked onto sucrose peptone agar plates and incubated at $24^{\circ} \mathrm{C}$. After 3 to 5 days, these plates were examined for bacterial growth. Nonsterilized leaf spot pieces were also excised and mounted in water on glass slides to examine for bacterial streaming with a compound microscope.

Characterization of Stemphylium isolates. Stemphylium fungi recovered from spinach leaf spots were grown in petri plates containing either PDA or $20 \%$ V8 juice agar (9) and incubated under lights. After 2 weeks, small masses of mycelium were mounted in $1 \%$ Tween 20 on a microscope slide and examined for morphological features. To better observe conidial surface textures, small amounts of mycelium were mounted in $0.05 \%$ sodium hypochlorite on a separate slide to effect bleaching of conidial pigments.

To measure colony linear growth rates, five $100-\mathrm{mm}$ petri plates containing $20 \%$ V8 juice agar were inoculated with a 6mm-diameter agar plug of actively growing mycelium from each of seven isolates. Duplicate sets of plates were incubated at 18 and $24^{\circ} \mathrm{C}$. Colony diameters were measured after 4,6 , and 8 days, and a mean was derived for the measurements of each set of five plates.

Long incubation periods often are necessary for the formation of the Pleospora perfect states of Stemphylium species $(15,20,34)$. To test isolates for the production of the teleomorph, carrot slice agar was prepared by cutting thin ( $<3 \mathrm{~mm}$ thick) transverse slices of raw carrot root, autoclaving the slices in distilled water for 10 min, then adding three slices to each ExtraDeep 100-mm-diameter petri plate (Fisher Scientific Co., Pittsburgh, PA) prior to adding $70 \mathrm{ml}$ of autoclaved $2 \%$ water agar. Additional Extra-Deep petri plates containing $70 \mathrm{ml}$ of $20 \% \mathrm{~V} 8$ juice agar or $33 \%$ malt extract agar (Difco) were also prepared. Because cellophane strips might facilitate perithecial development $(10,28)$, 
autoclaved cellophane strips $(2 \times 4 \mathrm{~cm})$ were placed on the agar surfaces of the V8 juice and malt extract media. Separate sets of carrot slice, V8 juice, and malt extract agar media were each inoculated with one 6-mm-diameter agar plug of seven isolates (three plates per isolate per medium), placed into plastic boxes, then incubated in the dark at 5,18 , or $24^{\circ} \mathrm{C}$ for up to 10 months. An additional set of inoculated plates was incubated following a protocol similar to that developed by Leach (20): inoculated plates were incubated in the dark at $5^{\circ} \mathrm{C}$ for 10 days and then incubated in the dark at $18^{\circ} \mathrm{C}$ for the remainder of the experiment. Observations were made monthly.

Pathogenicity of Stemphylium botryosum isolates to spinach. To test for pathogenicity on spinach, eight representative isolates of $S$. botryosum were grown for 4 weeks on V8 juice agar plates under the 12-h light-dark regime. Conidial suspensions $\left(10^{4}\right.$ conidia per $\left.\mathrm{ml}\right)$ were prepared and sprayed with a hand-held mister until runoff onto 24 spinach (cv. Bolero) plants at the four- to six-true-leaf stage. Plants were incubated in a humidity chamber maintained at $100 \%$ relative humidity $(\mathrm{RH})$ for $72 \mathrm{~h}$ and then incubated in a greenhouse $\left(20\right.$ to $\left.24^{\circ} \mathrm{C}\right)$. Control plants were sprayed with distilled water and handled in the same way. If symptoms developed on inoculated plants, isolations were conducted as previously described. The inoculation and isolation experiments were conducted three times.

To evaluate the responses of various spinach cultivars to the pathogen, conidial suspensions of four isolates (98-01, 98-03, 98-04, 98-07) were prepared as previously described and sprayed onto 12 plants each of 10 flat leaf, 8 semi-savoy, and 2 savoy spinach cultivars at the four- to six-trueleaf stage (Table 1). A water control was included for each cultivar. After 2 weeks, plants were evaluated for symptom severity according to the following scale: $-=$ no symptoms; $+=$ small $(<5 \mathrm{~mm}$ diameter $)$ leaf spots; $++=$ medium $(>5 \mathrm{~mm}$ diameter $)$ leaf spots. Isolations were conducted on representative leaf spots to confirm the presence of the pathogen. The experiment was conducted twice.
Pathogenicity of $S$. botryosum to other plants. To investigate the host range of the spinach isolates of $S$. botryosum, conidial suspensions of the four isolates used previously were prepared and sprayed onto the following plants: alfalfa (Medicago sativa cv. DK 189), bean (Phaseolus vulgaris cv. Blue Lake), beet (Beta vulgaris cv. Early Wonder), carrot (Daucus carota subsp. sativus cv. World Vision), endive (Cichorium endivia cv. Frisee), fava bean (Vicia faba

Table 1. Pathogenicity of Stemphylium botryosum to various spinach cultivars

\begin{tabular}{|c|c|c|c|c|c|}
\hline \multirow[b]{2}{*}{ Spinach cultivar ${ }^{\mathrm{z}}$} & \multicolumn{5}{|c|}{ Disease rating for Stemphylium isolates and control ${ }^{y}$} \\
\hline & 98-01 & 98-03 & 98-04 & 98-07 & Water \\
\hline \multicolumn{6}{|l|}{ Flat leaf } \\
\hline Bolero & ++ & ++ & ++ & ++ & - \\
\hline Nordic IV & ++ & ++ & ++ & ++ & - \\
\hline Polka & ++ & ++ & ++ & + & - \\
\hline Poncho & ++ & ++ & ++ & ++ & - \\
\hline Rushmore & ++ & ++ & ++ & ++ & - \\
\hline Shasta & ++ & ++ & ++ & ++ & - \\
\hline Space & + & ++ & ++ & ++ & - \\
\hline Spinnaker & ++ & ++ & + & ++ & - \\
\hline Springfield & ++ & ++ & ++ & ++ & - \\
\hline Unipak 131 & ++ & ++ & ++ & ++ & - \\
\hline \multicolumn{6}{|l|}{ Semi-savoy } \\
\hline Tyee & ++ & ++ & ++ & ++ & - \\
\hline Skookum & ++ & ++ & ++ & ++ & - \\
\hline $86-70$ & ++ & ++ & ++ & ++ & - \\
\hline $88-130$ & ++ & ++ & ++ & ++ & - \\
\hline $88-212$ & ++ & ++ & ++ & ++ & - \\
\hline $88-310$ & ++ & ++ & ++ & ++ & - \\
\hline $90-252$ & ++ & ++ & ++ & ++ & - \\
\hline $91-248$ & ++ & ++ & ++ & ++ & - \\
\hline \multicolumn{6}{|l|}{ Savoy } \\
\hline Vienna & + & + & + & + & - \\
\hline Samish & ++ & ++ & ++ & ++ & - \\
\hline
\end{tabular}

y Plants were evaluated after 2 weeks for disease severity by using the following rating scale: $-=$ no symptoms $;+=$ small $(<5 \mathrm{~mm}$ diameter $)$ leaf spots $;++=$ medium $(>5 \mathrm{~mm}$ diameter $)$ leaf spots. The inoculations were carried out two times and the results for the two tests were the same.

${ }^{\mathrm{z}}$ All plants were at the four- to six-true-leaf stage when spray inoculated with conidial suspensions $\left(10^{4}\right.$ conidia per $\left.\mathrm{ml}\right)$. Controls were sprayed with sterile water. Plants were incubated in a humidity chamber for $72 \mathrm{~h}$, then maintained in a greenhouse $\left(20\right.$ to $\left.24^{\circ} \mathrm{C}\right)$.
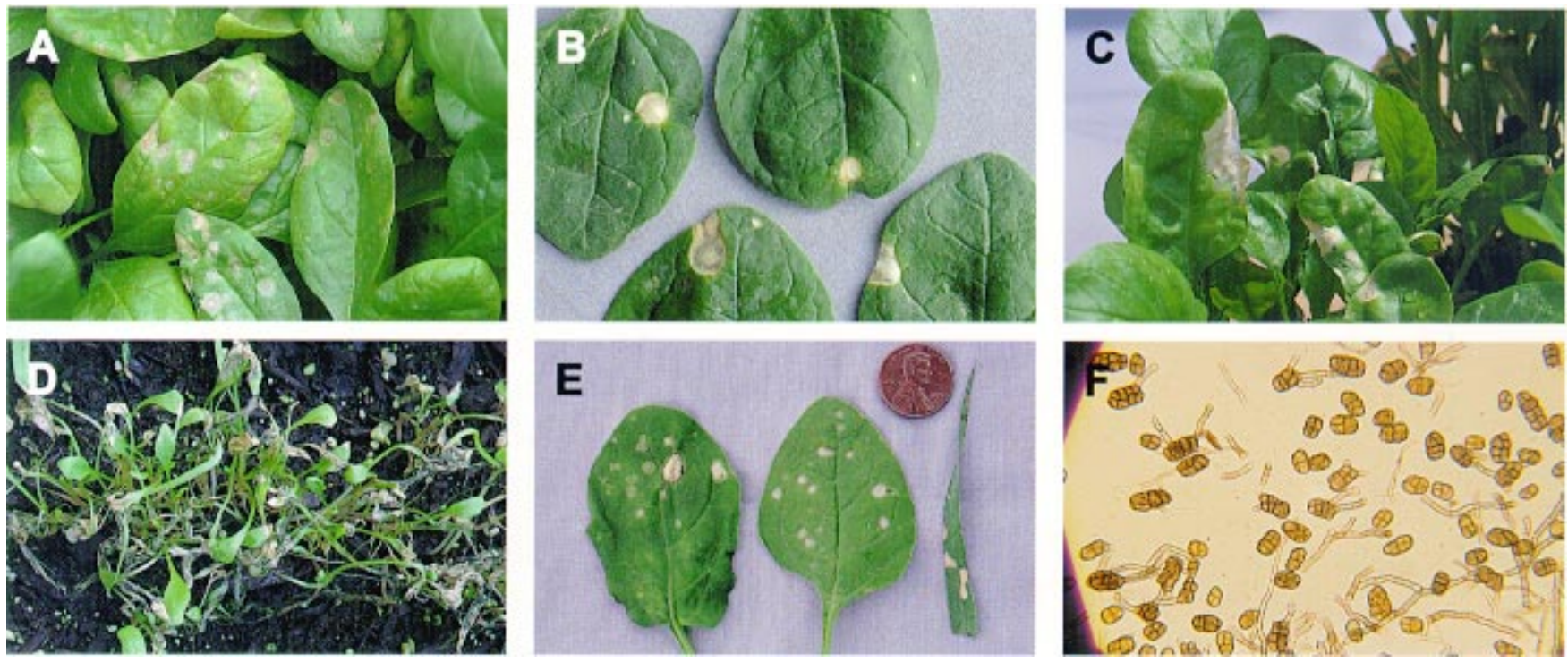

Fig. 1. Stemphylium leaf spot of spinach caused by Stemphylium botryosum. A, Initial symptoms consist of circular, gray-green leaf spots. B and C, In advanced stages of the disease, leaf spots are light tan and papery in texture and coalesce. Sporulation of the pathogen is generally absent. D, Infections on young spinach foliage can result in significant leaf death. E, Phytotoxicity from herbicide drift, pictured here on spinach and weed leaves, resembles Stemphylium leaf spot. F, Conidia of $S$. botryosum from 21 -day-old V8 juice agar cultures (images were photographed at $\times 400$ ). 
cv. Bell), lettuce (Lactuca sativa cvs. Esmeralda, Green Supreme, Green Towers, Red Salad Bowl, Salinas), landino clover Mix), onion (Allium cepa cv. Stockton Early Yellow), parsley (Petroselinum crispum cv. Moss Curled), pea (Pisum sativum cv. Alaska), radish (Raphanus sativum cv. Scarlett Globe), sugar beet (Beta vulgaris cv. Spreckels), yellow sweet clover (Melilotus officinalis), tall fescue (Festuca arundinacea cv. Apache II), and tomato (Lycopersicon esculentum cv. Shady Lady) (Table 2). A Chenopodium weed, nettleleaf goosefoot $(C$. murale), was also inoculated. Spinach (cv. Bolero) was inoculated as a positive control. Water served as a control for all plants. The plants used in this experiment were selected because $S$. botryosum has been reported as a pathogen $(1,9,12,14,22,25-27,29,31,37)$ or they were closely related to spinach (beet, sugar beet, nettleleaf goosefoot). Disease symptoms were evaluated after 2,3 , and 4 weeks using the same rating scale as described for the spinach pathogenicity tests. The experiment was carried out twice.

Examination of phytotoxin production. Because some isolates of Stemphylium produce phytotoxins $(3,5,8)$, we tested the spinach isolates of $S$. botryosum for production of toxic substances. Liquid fungal cultures were grown by placing five mycelial plugs per isolate into $300 \mathrm{ml}$ of sterilized culture medium in 3-liter lowform flasks. Flasks were not shaken and (Trifolium repens), lupine (Lupinus Russell's

were incubated for 21 days at $23^{\circ} \mathrm{C}$. The liquid medium was that of Karr et al., as modified by Barash et al. $(3,16)$. Four spinach isolates (98-01, 98-03, 98-04, 98$07)$ were prepared in this way as well as two controls: a culture of a Stemphylium sp. isolated from alfalfa leaves, and uninoculated culture medium.

After 21 days, cell-free culture filtrates (CFCFs) were prepared by successively filtering each culture through two layers of cheesecloth, Whatman no. 2 filter paper, and a millipore filter $(0.2-\mu \mathrm{m}$ pore size $)$. The resulting solutions were applied to potted test plants by first making a cluster of five to six puncture wounds on adaxial leaf surfaces with a syringe needle, then applying $30 \mu \mathrm{l}$ of solution to the top of each wound. For each cultivar tested, four fully expanded and four immature leaves were treated. After treatment, plants were kept in a greenhouse (20 to $24^{\circ} \mathrm{C}$ ) for observation. Test plants were 7 to 8 weeks old and were the following: bean (cv. Blue Lake), cauliflower (Brassica oleracea var. botrytis cv. Icecap), lettuce (cv. Alpha), spinach (cv. Spinnaker), and tomato (cv. Shady Lady). Leaves were examined at 12, 24,48 , and $72 \mathrm{~h}$ for symptoms of phytotoxic damage. The experiment was completed twice.

\section{RESULTS}

Isolation of the causal agent. Leaf spot surfaces generally did not have visible

Table 2. Pathogenicity of Stemphylium botryosum to various commercial crops and Chenopodium murale

\begin{tabular}{|c|c|c|c|c|c|c|}
\hline \multirow[b]{2}{*}{ Planty } & \multirow[b]{2}{*}{ Cultivar $^{\mathrm{z}}$} & \multicolumn{5}{|c|}{ Disease rating for Stemphylium isolates and control } \\
\hline & & 98-01 & 98-03 & 98-04 & 98-07 & Water \\
\hline Alfalfa & DK 189 & - & - & - & - & - \\
\hline Bean & Blue Lake & - & _- & _- & - & - \\
\hline Beet & Early Wonder & _- & - & _- & - & _- \\
\hline Carrot & World Vision & - & - & - & - & - \\
\hline Endive & Frisee & _- & - & _- & - & _- \\
\hline Fava bean & Bell & - & - & - & + & - \\
\hline Lettuce & Esmeralda & _- & _- & _- & _- & _- \\
\hline Lettuce & Green Supreme & - & - & - & - & - \\
\hline Lettuce & Green Towers & - & - & - & - & - \\
\hline Lettuce & Red Salad Bowl & _- & _- & - & _- & _- \\
\hline Lettuce & Salinas & - & - & - & - & - \\
\hline Landino clover & n.a. & _- & _- & _- & _- & _- \\
\hline Lupine & Russell's Mix & - & - & - & - & - \\
\hline Onion & Stockton Early Yellow & - & _- & - & - & - \\
\hline Parsley & Moss Curled & - & - & - & - & - \\
\hline Pea & Alaska & - & - & - & - & - \\
\hline Radish & Scarlett Globe & - & _- & _- & _- & - \\
\hline Sugar beet & Spreckels & - & - & - & - & - \\
\hline Sweet clover & n.a. & - & - & - & - & - \\
\hline Tall fescue & Apache II & - & - & - & - & - \\
\hline Tomato & Shady Lady & - & - & - & - & - \\
\hline \multicolumn{2}{|c|}{ Chenopodium murale } & - & - & - & - & - \\
\hline Spinach & Bolero & ++ & ++ & ++ & ++ & - \\
\hline
\end{tabular}

${ }^{x}$ Plants were evaluated after 2,3 , and 4 weeks for disease severity by using the following rating scale: $-=$ no symptoms; $+=$ small $(<5 \mathrm{~mm}$ diameter $)$ leaf spots; $++=$ medium $(>5 \mathrm{~mm}$ diameter $)$ leaf spots. The inoculations were carried out two times and the results for the two tests were the same.

y All plants were at the four- to six-true-leaf stage when spray inoculated with conidial suspensions $\left(10^{4}\right.$ conidia per $\left.\mathrm{ml}\right)$. Controls were sprayed with sterile water. Plants were incubated in a humidity chamber for $72 \mathrm{~h}$, then maintained in a greenhouse $\left(20\right.$ to $\left.24^{\circ} \mathrm{C}\right)$.

${ }^{\mathrm{z}}$ n.a. $=$ not applicable. fungal growth, and leaf spot cut edges lacked bacterial streaming. No bacteria were recovered from the leaf section suspensions streaked onto sucrose peptone agar plates. However, a fungus was consistently isolated from leaf spot tissue plated onto acidified PDA. Monoconidial cultures of representative isolates were stored on PDA slants at $5^{\circ} \mathrm{C}$ for further studies.

Characterization of Stemphylium spp. isolated from spinach. All isolates of Stemphylium recovered from symptomatic spinach leaves were morphologically similar. When incubated on PDA under lights, isolates produced dense aerial mycelium that was green-brown to green-gray in color, interspersed with large patches of white mycelium, and lacked conidia. However, on V8 juice agar incubated under lights, the isolates produced dark greenbrown mycelium and abundant conidia after approximately 10 days. Conidiophores were mostly unbranched, $5 \mu \mathrm{m}$ wide, with distinctly swollen apical cells (7 $\mu \mathrm{m}$ wide) having darkly pigmented bands (Table 3). Dictyoconidia were brown colored, broadly ellipsoidal to broadly ovoid, and borne singly (Fig. 1). A conspicuous constriction was present at the median transverse septum. Outer conidial walls had verrucose ornamentation. Conidia dimensions were mostly 19 to $28 \times 14$ to $19 \mu \mathrm{m}$, and the mean length:width ratio was 1.46 (Table 3). The fungus was identified as Stemphylium botryosum Wallroth $(4,11,13,24,32-34,38)$. For seven isolates, mean colony linear growth rates at 18 and $24^{\circ} \mathrm{C}$ were 0.62 and $0.85 \mathrm{~cm} /$ day, respectively (Table 4).

Stock cultures of $S$. botryosum, stored continuously at $5^{\circ} \mathrm{C}$ on PDA slants, developed mature ascospores after 7 to 8 months. However, none of the isolates cultured on either carrot slice, V8 juice, or malt extract medium formed ascospores after 10 months incubation at 5, 18, or $24^{\circ} \mathrm{C}$. Plates incubated at $24^{\circ} \mathrm{C}$ contained only mycelium; plates incubated at 5 or $18^{\circ} \mathrm{C}$ had a few structures that appeared to be ascomata but which lacked asci. The set of plates incubated first at $5^{\circ} \mathrm{C}$ for 10 days then at $18^{\circ} \mathrm{C}$ for 9 months likewise contained only a few immature ascomata. In all plates, such structures formed randomly or in concentric rings and were not associated with the cellophane strips.

Ascospores produced from PDA slants of all isolates were similar in appearance and morphology (Table 3). Mature ascospores were dictyospores, clavate with rounded ends, and brown in color. Ascospores consistently had seven transverse septa, usually one complete longitudinal septum extending along the length of the spore, and several incomplete longitudinal septa. Conidia dimensions were 33 to $36 \times$ 11 to $14 \mu \mathrm{m}$ (Table 3). The fungus was identified as Pleospora herbarum (Fries) Rabenhorst (4,13,33-35). 
Pathogenicity of $S$. botryosum to spinach. When eight representative spinach isolates were inoculated onto spinach cv. Bolero plants, circular, graygreen leaf spots developed after 1 week and were similar to those observed on diseased plants in the field. By the second week, these spots turned the characteristic tan color and generally lacked any visible signs of fungal infection. Stemphylium fungi morphologically similar to the original isolates were consistently isolated from the leaf spots and after characterization were confirmed to be identical to the original isolates. None of the control plants treated with sterile distilled water developed symptoms. Results from the three experiments were consistent.

All 10 flat leaf, 8 semi-savoy, and 2 savoy spinach cultivars developed leaf spots after 2 weeks when inoculated with four isolates of $S$. botryosum. Symptoms were similar to those observed in commercial fields. Differences in disease severity among the cultivars were slight, with cvs. Polka, Space, and Spinnaker exhibiting slightly smaller leaf spots than other cultivars when inoculated with isolates 98-07, 98-01, and 98-04, respectively (Table 1). The savoy cv. Vienna had smaller leaf spots than other cultivars when inoculated with all four isolates. None of the control plants treated with sterile distilled water developed symptoms. Results from the two experiments were similar.

Pathogenicity of $S$. botryosum to other plants. After 2, 3, and 4 weeks, disease symptoms did not develop on the 21 selected plants and one weed species inoculated with four representative isolates. However, one isolate (98-07) caused small ( $<2 \mathrm{~mm}$ diameter) leaf spots on fava bean (Table 2). All spinach controls developed leaf spots similar to those observed in other experiments. Stemphylium fungi morphologically similar to the original isolates were isolated only from the spinach controls and the fava bean inoculated with isolate 98-07. None of the control plants treated with sterile distilled water developed symptoms. Results from both experiments were similar.
Examination of phytotoxin production. None of the CFCFs of the four isolates of $S$. botryosum caused any symptoms of phytotoxic damage to punctured leaves of the five plant cultivars after $72 \mathrm{~h}$. Likewise, the CFCFs of the Stemphylium sp. from alfalfa and sterile culture medium did not cause any symptoms. Results from both tests were the same.

\section{DISCUSSION}

This is the first report of Stemphylium leaf spot of spinach caused by $S$. botryosum. We have placed a voucher specimen in the University of California Herbarium (accession no. 1,726,619). The only previous report of a Stemphylium species associated with spinach indicated that the fungus caused spinach seed mold $(2,12)$. While $S$. botryosum is usually considered a saprobe or weak pathogen, our studies demonstrated that the spinach isolates were primary pathogens and can cause significant damage. The disease occurred in sporadic outbreaks in various fields in coastal California beginning in 1997 and each year thereafter. Our spinach isolates apparently do not produce a phytotoxin; however, additional research is needed to confirm this preliminary observation.

Stemphylium leaf spot on mature foliage in the field could be confused with initial symptoms of Cladosporium leaf spot or phytotoxic damage caused by pesticide sprays or fertilizer applications. Prior to 1997, the University of California Cooperative Extension Diagnostic Laboratory in Salinas had received samples of spinach having symptoms resembling those of Stemphylium leaf spot; however, because of the close resemblance to chemical burn, such samples were not further analyzed. It is possible, therefore, that Stemphylium leaf spot had occurred in California prior to 1997 but was misdiagnosed as chemical damage.

$S$. botryosum is reported as a leaf spot pathogen on numerous crops, including: alfalfa, bean, beet, cotton, fava bean, lettuce, landino clover, lupine, onion, parsley, pea, sugar beet, sweet clover, and tomato $(1,2,9,10,12,14,22,25-27,29-31,36,37)$.

This fungus is also associated with seed and other tissues of various crops (carrot, radish, tall fescue) (12). However, when the spinach isolates of $S$. botryosum were inoculated onto cultivars of many of these crops, symptoms did not develop. On the basis of these inoculation experiments, it appears that this spinach pathogen has a narrow host range and does not infect plants other than spinach. The spinach isolates may be a distinct forma specialis within $S$. botryosum, although additional investigations would be appropriate to confirm this conclusion. Previous forma specialis designations have been suggested for other Stemphylium pathogens, such as $S$. botryosum f. sp. lactucae for isolates infecting only lettuce (26) and S. botryosum $\mathrm{f}$. sp. lycopersici for isolates infecting only tomato (30).

In identifying this spinach leaf spot pathogen as $S$. botryosum Wallroth, we have followed Wiltshire (38), who had examined Wallroth's holotype and fur-

Table 4. Colony diameters and linear growth rates of Stemphylium botryosum

\begin{tabular}{lcccc}
\hline & \multicolumn{3}{c}{ Mean + s colony diameters $(\mathbf{c m})^{\mathbf{y}}$} & \multirow{2}{*}{$\begin{array}{c}\text { Linear growth } \\
\text { rate }(\mathbf{c m} / \text { day })^{\mathbf{z}}\end{array}$} \\
\cline { 2 - 4 } Temp. & Day 4 & Day 6 & Day 8 & \\
\hline $18^{\circ} \mathrm{C}$ & $2.17+0.20$ & $3.60+0.14$ & $4.65+0.24$ & 0.62 \\
$24^{\circ} \mathrm{C}$ & $3.83+0.14$ & $5.59+0.21$ & $7.24+0.22$ & 0.85 \\
\hline
\end{tabular}

y Five V8 juice agar plates for each of seven isolates were inoculated with a 6-mm-diameter agar plug of actively growing mycelia. Sets of plates were incubated at 18 and $24^{\circ} \mathrm{C}$. Colony diameters were measured at 4,6 , and 8 days, and a mean was derived for the measurements of each five-plate set. For each temperature and time period, measurements for the seven isolates were combined into a mean $+\mathrm{s}$, with $\mathrm{s}=$ standard deviation of the mean.

${ }^{\mathrm{z}}$ Linear growth rate was calculated by determining the differences in diameter between 4 and 8 days growth and dividing these values by 4 (number of days between measurements).

Table 3. Dimensions of conidia of Stemphylium botryosum and ascospores of Pleospora herbarum

\begin{tabular}{|c|c|c|c|c|c|}
\hline \multirow[b]{2}{*}{ Structure $^{\mathrm{z}}$} & \multirow[b]{2}{*}{ 98-01 } & \multicolumn{2}{|c|}{ Isolate measurements $(\mu \mathrm{m})$} & \multirow[b]{2}{*}{ 98-07 } & \multirow{2}{*}{$\begin{array}{l}\text { Isolate } \\
\text { means }\end{array}$} \\
\hline & & 98-03 & 98-04 & & \\
\hline \multicolumn{6}{|l|}{ Conidia } \\
\hline Length & (19-) 19-28 (-31) & (19-) 25-28 (-33) & (19-) 19-28 (-31) & (19-) 22-28 (-31) & 25 \\
\hline Width & (14-) 14-17 (-19) & (14-) $17-19(-19)$ & (11-) 14-19 (-22) & (14-) $17-19(-22)$ & 17 \\
\hline Mean length/width ratio & 1.50 & 1.45 & 1.44 & 1.43 & 1.46 \\
\hline \multicolumn{6}{|l|}{ Conidiophores } \\
\hline Width & 5 & 5 & 5 & 5 & 5 \\
\hline Apical cell width & 7 & 7 & 7 & 7 & 7 \\
\hline \multicolumn{6}{|l|}{ Ascospores } \\
\hline Length & (31-) 33-36 (-39) & (33-) 33-39 (-39) & (31-) 33-36 (-39) & (31-) 33-36 (-36) & 35 \\
\hline Width & (11-) $11-14(-14)$ & (11-) $11-14(-17)$ & (11-) $11-14(-14)$ & (11-) $11-14(-14)$ & 13 \\
\hline
\end{tabular}

$\overline{\mathrm{z}}$ Fungal structures were taken from either 4-week-old V8 juice agar plates (Stemphylium botryosum conidia and conidiophores) or 8-month-old potato dextrose agar slants (Pleospora herbarum ascospores). For each isolate, 50 spores and 20 conidiophores were measured. 
nished illustrations from that original specimen. Wiltshire also examined Stemphylium samples of other researchers and listed some of these fungi as synonyms of $S$. botryosum. Although his sketches of the holotype show great uniformity in conidial morphology, his writings indicate that he held a very broad view of the species, allowing for much variation in conidial size and the effects of environment on conidial morphology. Our isolates fit descriptions and illustrations of the holotype as recorded by Wiltshire and other mycologists $(24,38)$.

Regarding the teleomorph, Wiltshire recognized Pleospora herbarum (Fries) Rabenhorst as the perfect stage of $S$. botryosum and also observed that Pleospora perithecia were on the same stem and associated with Wallroth's type. In the case of the spinach pathogen, ascomata and ascospores have been observed to form only in culture on agar in tubes, in darkness, at $5^{\circ} \mathrm{C}$, after 7 to 8 months. Ascomata are very large and extremely irregular in shape. Simmons (34) has redefined one species ( $P$. herbarum) and created a new species ( $P$. tarda Simmons) based upon maturation times of ascomata and dimensions of ascospores. The difficulty with this proposed arrangement is that the spinach isolates do not fit well in either category. Our isolates mature their ascocarps slowly and in this respect resemble $P$. tarda. The same isolates, though, have ascospore dimensions that more closely fit $P$. herbarum. Hence we have little confidence in assigning a teleomorph name to the spinach pathogen, although the history of $S$. botryosum, which allows for wide variation, suggests we use $P$. herbarum Rab. Note that Simmons (34) makes $S$. botryosum the anamorph of $P$. tarda. It is evident that additional study and examination of many more isolates from various hosts would be necessary to further define the taxonomic relationships of such a variable genus.

Following the spring rains in 2000, Stemphylium leaf spot again developed in limited acreage in coastal California spinach fields. This continued occurrence perhaps indicates that the pathogen is becoming established in the state. Although no study has yet examined the epidemiology of Stemphylium leaf spot of spinach, the development of this disease during the rainy season and in fields irrigated with overhead sprinklers indicates that splashing water and free moisture likely aide in the distribution of $S$. botryosum conidia and create conditions favorable for infection and disease development. While downy mildew and Cladosporium leaf spot are typically the most destructive diseases of the spinach crop, the addition of Stemphylium leaf spot adds yet another challenge that California growers must overcome in producing highquality, defect-free spinach.

\section{ACKNOWLEDGMENTS}

We thank the following persons for assisting with this study: T. Angel, M. Borzini, T. Galdos, D. G. Gilchrist, T. G. Gonzales, D. Haviland, T. Hussar, S. Lanini, T. Morelock, D. Putnam, D. M. Rizzo, E. G. Simmons, and B. Ward. We acknowledge $\mathrm{S}$. Nishihara for calling our attention to this new disease and M. Butler for special assistance. The first author thanks J. D. MacDonald, R. M. Bostock, and the Department of Plant Pathology at the University of California, Davis, for the use of department facilities, and he especially thanks E. E. Butler for guidance and encouragement. This research was supported in part by grants awarded to the first author by the following: University of California Cooperative Extension Assembly Council Fellowship for Advanced Studies, 1997; the Department of Agronomy Milton D. and Mary M. Miller Plant Science Award for 1997-1998, University of California, Davis.

\section{LITERATURE CITED}

1. Abdou, Y. A., and Fahim, M. M. 1969. A Stemphylium leaf spot of Vicia faba in the United Arab Republic. Plant Dis. Rep. 53:157-159.

2. Alfieri, S. A., Jr., Langdon, K. R., Kimbrough, J. W., El-Gholl, N. E., and Wehlburg, C. 1994. Diseases and Disorders of Plants in Florida. Bull. no. 14. Florida Department of Agriculture and Consumer Services, Division of Plant Industry, Gainesville.

3. Barash, I., Karr, A. L., and Strobel, G. A. 1975. Isolation and characterization of Stemphylin, a chromone glucoside from Stemphylium botryosum. Plant Physiol. 55:646651.

4. Booth, C., and Pirozynski, K. A. 1967. Pleospora herbarum. C.M.I. Descriptions of Pathogenic Fungi and Bacteria. Kew, Surrey, England.

5. Borges, O. L., Stanford, E. H., and Webster, R. K. 1976. The host-pathogen interaction of alfalfa and Stemphylium botryosum. Phytopathology 66:749-753.

6. California Agricultural Statistics Service. 1997. County Agricultural Commissioners' Data. Calif. Agric. Stat. Serv., Sacramento, CA.

7. Correll, J. C., Morelock, T. E., Black, M. C., Koike, S. T., Brandenberger, L. P., and Dainello, F. J. 1994. Economically important diseases of spinach. Plant Dis. 78:653-660.

8. Cowling, W. A. 1980. Environmental, genetic, and physiological factors influencing disease severity in Stemphylium leaf spot of alfalfa in California. Ph.D. diss. University of California, Davis.

9. Cowling, W. A., and Gilchrist, D. G. 1980. Influence of the pathogen on disease severity in Stemphylium leafspot of alfalfa in California. Phytopathology 70:1148-1153.

10. Cowling, W. A., Gilchrist, D. G., and Graham, J. H. 1981. Biotypes of Stemphylium botryosum on alfalfa in North America. Phytopathology 71:679-684.

11. Ellis, M. B. 1971. Dematiaceous Hyphomycetes. Commonwealth Mycological Institute, London, England.

12. Farr, D. F., Bills, G. F., Chamuris, G. P., and Rossman, A. Y. 1989. Fungi on Plants and Plant Products in the United States. American Phytopathological Society, St. Paul, MN.

13. Gilchrist, D. G., and Simmons, E. G. 1990. Stemphylium leaf spot. Pages 17-20 in: Compendium of Alfalfa Diseases, 2nd ed. D. L. Stuteville and D. C. Erwin, eds. American Phytopathological Society, St. Paul, MN.

14. Graham, J. H., and Zeiders, K. E. 1960. Pathogenicity and morphology of some leguminicolous and related species of Stem- phylium. Phytopathology 50:757-760.

15. Irwin, J. A. G., Dill-Macky, R., and Stirling, M. 1986. Taxonomic studies on Australian isolates of Stemphylium spp. and associated teleomorphs. Aust. J. Bot. 34:281-292.

16. Karr, A. L., Karr, D. B., and Strobel, G. A. 1974. Isolation and partial characterization of four host-specific toxins of Helminthosporium maydis (race T). Plant Physiol. 53:250-257.

17. Koike, S. T., and Correll, J. C. 1993. First report of spinach anthracnose caused by Colletotrichum dematium in California. Plant Dis. 77:318.

18. Koike, S. T., Henderson, D. M., and Butler, E. E. 1999. A new leaf spot disease of spinach in California caused by Stemphylium botryosum. (Abstr.) Phytopathology 89:S40.

19. Koike, S. T., Smith, R. F., and Schulbach, K. F. 1992. Resistant cultivars, fungicides combat downy mildew of spinach. Calif. Agric. 46:29-31

20. Leach, C. M. 1971. Regulation of perithecium development and maturation in Pleospore herbarum by light and temperature. Trans. Br. Mycol. Soc. 57:295-315.

21. LeStrange, M., Koike, S. T., Valencia, J., and Chaney, W. 1996. Spinach production in California. Vegetable Production Series. DANR Publ. 7212.

22. Lewis, G. D. 1962. Stemphylium leaf spot of parsley. (Abstr.) Phytopathology 52:925.

23. National Agricultural Statistics Service. 1997. U.S. Vegetable Commodity Rankings. United States Department of Agriculture.

24. Neergaard, P. 1945. Danish Species of Alternaria and Stemphylium. Einar Munksgaard, Copenhagen, Denmark.

25. Nelson, R. R. 1955. Studies on Stemphylium leafspot of alfalfa. Phytopathology 45:352356.

26. Padhi, B., and Snyder, W. C. 1954. Stemphylium leaf spot of lettuce. Phytopathology 44:175-180.

27. Raid, R. N. 1997. Stemphylium leaf spot. Pages 25-26 in: Compendium of Lettuce Diseases. R. M. Davis, K. V. Subbarao, R. N. Raid, and E. A. Kurtz, eds. American Phytopathological Society, St. Paul, MN.

28. Ramsey, R. H. 1965. Genetic interaction between closely related genotypes of Pleospora herbarum. Ph.D. diss. University of California, Davis.

29. Rotem, J., and Bashi, E. 1977. A review of the present status of the Stemphylium complex in tomato foliage. Phytoparasitica 5:45-58

30. Rotem, J., Cohen, Y., and Wahl, I. 1966. A new tomato foliage disease in Israel caused by Stemphylium botryosum. Can. J. Plant Sci. 46:265-270.

31. Shishkoff, N., and Lorbeer, J. W. 1989. Etiology of Stemphylium leaf blight of onion. Phytopathology 79:301-304.

32. Simmons, E. G. 1967. Typification of Alter naria, Stemphylium, and Ulocladium. Mycologia 59:67-92.

33. Simmons, E. G. 1969. Perfect states of Stemphylium. Mycologia 61:1-26.

34. Simmons, E. G. 1985. Perfect states of Stemphylium. II. Sydowia 38:284-293.

35. Simmons, E. G. 1989. Perfect states of Stemphylium. III. Memoirs of the N.Y. Bot. Garden 49:305-307.

36. Sinclair, J. B., and Shatla, M. N. 1962. Stemphylium leaf spot of cotton reported from Louisiana. Plant Dis. Rep. 46:744.

37. Wells, H. D., Forbes, I., Webb, T. E., and Edwardson, J. R. 1956. Two Stemphylium diseases of blue lupine. Plant Dis. Rep. 40:803-806.

38. Wiltshire, S. P. 1938. The original and modern conceptions of Stemphylium. Trans. Br. Mycol. Soc. 21:211-239. 